\title{
Does Kiitricha (Protista, Ciliophora, Spirotrichea) belong to Euplotida or represent a primordial spirotrichous taxon? With suggestion to establish a new subclass Protohypotrichia
}

Correspondence
Weibo Song
wsong@ouc.edu.cn

\author{
Lifang Li, ${ }^{1,2}$ Chen Shao, ${ }^{1}$ Weibo Song, ${ }^{1}$ Denis H. Lynn, ${ }^{3}$ Zigui Chen ${ }^{1}$ \\ and Mann Kyoon Shin ${ }^{2}$ \\ ${ }^{1}$ Laboratory of Protozoology, KLM, Ocean University of China, Qingdao 266003, PR China \\ ${ }^{2}$ Department of Biology, University of Ulsan, Ulsan 680-749, Republic of Korea \\ ${ }^{3}$ Department of Integrative Biology, University of Guelph, Guelph, ON N1G 2W1, Canada
}

\section{INTRODUCTION}

Spirotrich ciliates, which represent one of the major adaptive radiations within the phylum Ciliophora, are divided into four major 'classical' assemblages, the hypotrichs, oligotrichs, choreotrichs and stichotrichs (Lynn, 2008; Lynn \& Small, 2002). These groups have been recognized as discrete clades for many years (Corliss, 1979; De Puytorac, 1994; Small \& Lynn, 1985). Among them, the hypotrichs and stichotrichs are usually considered together in terms of the evolution of the

Abbreviations: BI, Bayesian inference; DK, dorsal kineties; FVT, frontoventral-transverse; LS, least squares; ML, maximum likelihood; $\mathrm{NJ}$, neighbour joining; s. l., sensu lato; SSU, small subunit; UM, undulating membranes.

The GenBank/EMBL/DDBJ accession numbers for the SSU rRNA and partial alpha-tubulin gene sequences of Kiitricha marina are AY896768 and EF198664. The accession number for the deduced amino acid sequence of alpha-tubulin from K. marina is ABP96884. sporadically distributed cirri on the ventral surface of ciliates. Kinetosomes distributed in kineties in anteriorposterior rows are assumed to be a feature of the ancestor of hypotrichs and stichotrichs, and this is supported by the inclusion of a ciliate with a simple kinetid organization, Phacodinium, which is clustered at the base of the class Spirotrichea (Shin et al., 2000). Furthermore, Protocruzia, another ciliate with simple dikinetids arranged in anteriorposterior kineties, is also placed at the base of the spirotrich clade using small-subunit (SSU) rRNA gene sequences, although its position is somewhat variable (Hammerschmidt et al., 1996).

A third genus, Kiitricha, has also been considered among the basal hypotrichs sensu lato (s. l.). This genus has a unique and probably ancestral pattern of simple ciliated dikinetids for the dorsal ciliature, uniform and slightly differentiated cirri on the ventral side and no differentiation of real marginal rows (Fig. 1) (see also Song \& Wilbert, 1997). 

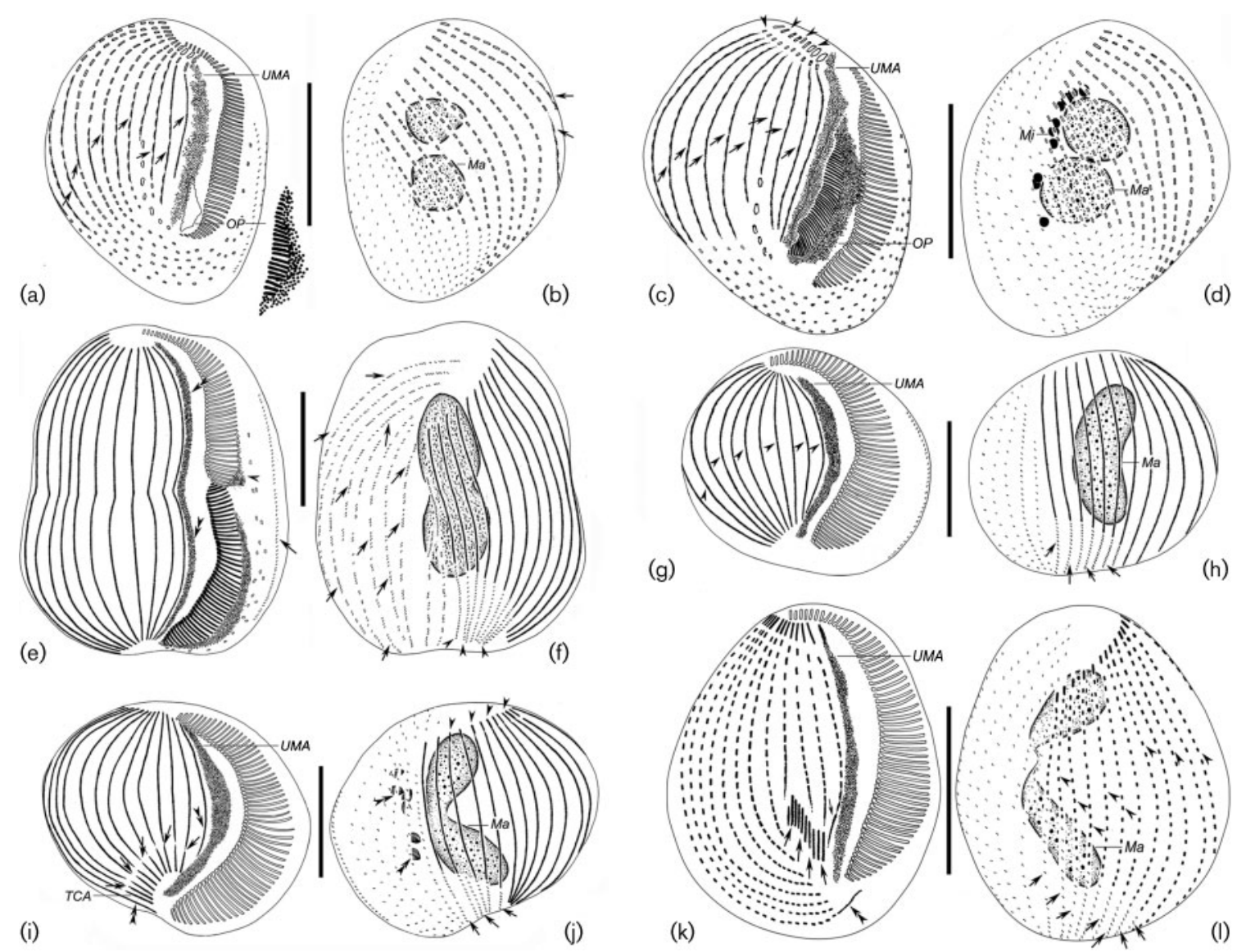

(d)

(k)
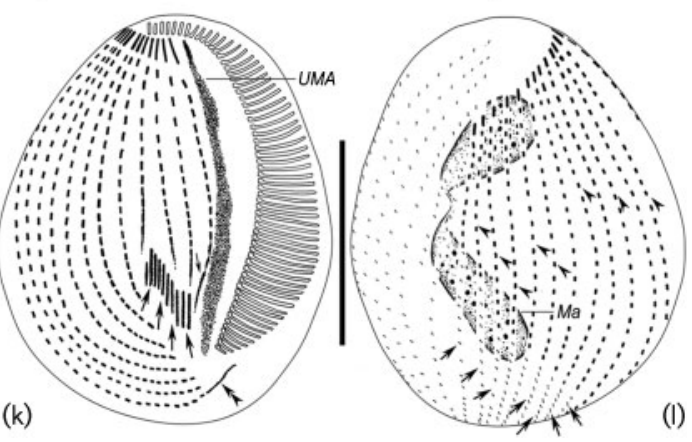

Fig. 1. Division morphogenesis in $K$. marina showing stages before $(a-f)$ and after $(g-l)$ cell division. (a, b) Ventral (a) and dorsal (b) views of an early stage divider (same specimen) to show that the oral primordium is formed on the dorsal wall of the buccal cavity. Note that the ventral cirri (arrows) and UM anlage (UMA) are dedifferentiated. (c, d) Ventral (c) and dorsal (d) views of a specimen. Arrows show the cirral anlagen and arrowheads indicate that the anteriormost cirri in each cirral row are still not dedifferentiated. Ma, Macronuclear nodule; Mi, micronucleus; OP, oral primordium. (e, $f$ ) Ventral (e) and dorsal ( $f$ ) views of a mid-stage divider. Arrows show that some dikinetids are more densely arranged, with proliferation of basal bodies in the old DK. In (e), double-arrowheads show that the UMA is prolonged with proliferation of basal bodies. Arrowhead indicates the proximal end of the old adoral zone with membranelles (AZM) dedifferentiated. Arrowheads in ( $f$ ) demonstrate the old DK. ( $g, h$ ) Ventral $(\mathrm{g})$ and dorsal $(\mathrm{h})$ views of the same specimen demonstrate the proter after the daughter cells have separated. Arrowheads in ( $\mathrm{g}$ ) show the cirral anlagen and arrows in (h) demonstrate the DK. ( $\mathrm{i}, \mathrm{j}$ ) Ventral (i) and dorsal (j) views of a middle divider. In (i), arrows show that the cirral anlagen differentiate the transverse cirral anlagen (TCA) and double-arrowheads indicate the first cirral anlagen. In (j), double-arrowheads show the micronuclei, arrowheads show the anteriormost cirri in each cirral row and arrows indicate the DK. $(k, I)$ Ventral $(k)$ and dorsal $(I)$ views of a very late divider after the daughter cells have separated. Note the division of the macronucleus. In $(k)$, arrows mark the TCA; double-arrowheads indicate that the end of the rightmost ventral cirral row is still an anlage-like structure, which might be the anlage for the left cirral row. In (I), arrows show the DK and arrowheads indicate that the segregation of the cirral anlagen is almost finished. Bars, $50 \mu \mathrm{m}$.

Lynn \& Small $(1997,2002)$ separated all known hypotrichs (s. l.) into the two subclasses Stichotrichia and Hypotrichia. The genus Kiitricha and its relatives were assigned to the latter, on the basis of a number of features: (i) both basal bodies in each dikinetid of the dorsal kineties (DK) are ciliated, a very unusual character in all known hypotrichs (s. l.), and some DK are a mixture of small cirri and dikinetids; (ii) no marginal rows are recognized, but many cirri are distributed onto the dorsal side, unique in all known 'hypotrichs'; and, (iii) except for the transverse cirri, there is no differentiation of cirri on the ventral side (i.e. cirri are not grouped, but rather are distributed in anterior-posterior files, like those at the segregating stage of cirral anlagen during morphogenesis) (Song \& Wilbert, 1997). In addition, Kiitricha has more than five transverse cirri, and so is remotely related to species with five frontoventral-transverse (FVT)-anlagen (i.e. all known euplotids). All these features indicate that Kiitricha might be an ancestral or 'basal' clade in relation to the 'typical' hypotrichs (s. l.). 
In order to assess the 'ancestral' position of Kiitricha within the Spirotrichea, the SSU rRNA and alpha-tubulin genes of Kiitricha marina Nozawa, 1941 were sequenced and analysed. With the combination of morphological and morphogenetic characters, our work provides molecular evidence to ascertain the phylogenetic position of this unusual group.

\section{METHODS}

Ciliate collection and identification. Kiitricha marina was collected from the coast near Qingdao, China $\left(36^{\circ} 08^{\prime} \mathrm{N} 120^{\circ} 43^{\prime}\right.$
E) (Fig. 2a-c, insets). Clonal cultures were established at room temperature for further analysis. Morphological and morphogenetic investigations were performed according to Song et al. (2004).

PCR amplification and sequencing. Cells were starved overnight and concentrated with low-speed centrifugation. Genomic DNA was extracted following Li \& Song (2006). To minimize PCR amplification errors, high-fidelity TaKaRa ExTaq was used to amplify target genes using the following oligonucleotide primers: for the SSU rRNA gene,: 5'-AACCTGGTTGATCCTGCCAGT-3' (forward) and $5^{\prime}$ TGATCCTTCTGCAGGTTCACCTAC-3' (reverse), and for the alpha-tubulin gene, 5'-AAGGCTCTCTTGGCGTACAT-3' (forward) and 5'-TGATGCCTTCAACACCTTCTT-3' (reverse). The typical amplification profile consisted of 5 min initial denaturation $\left(95^{\circ} \mathrm{C}\right)$

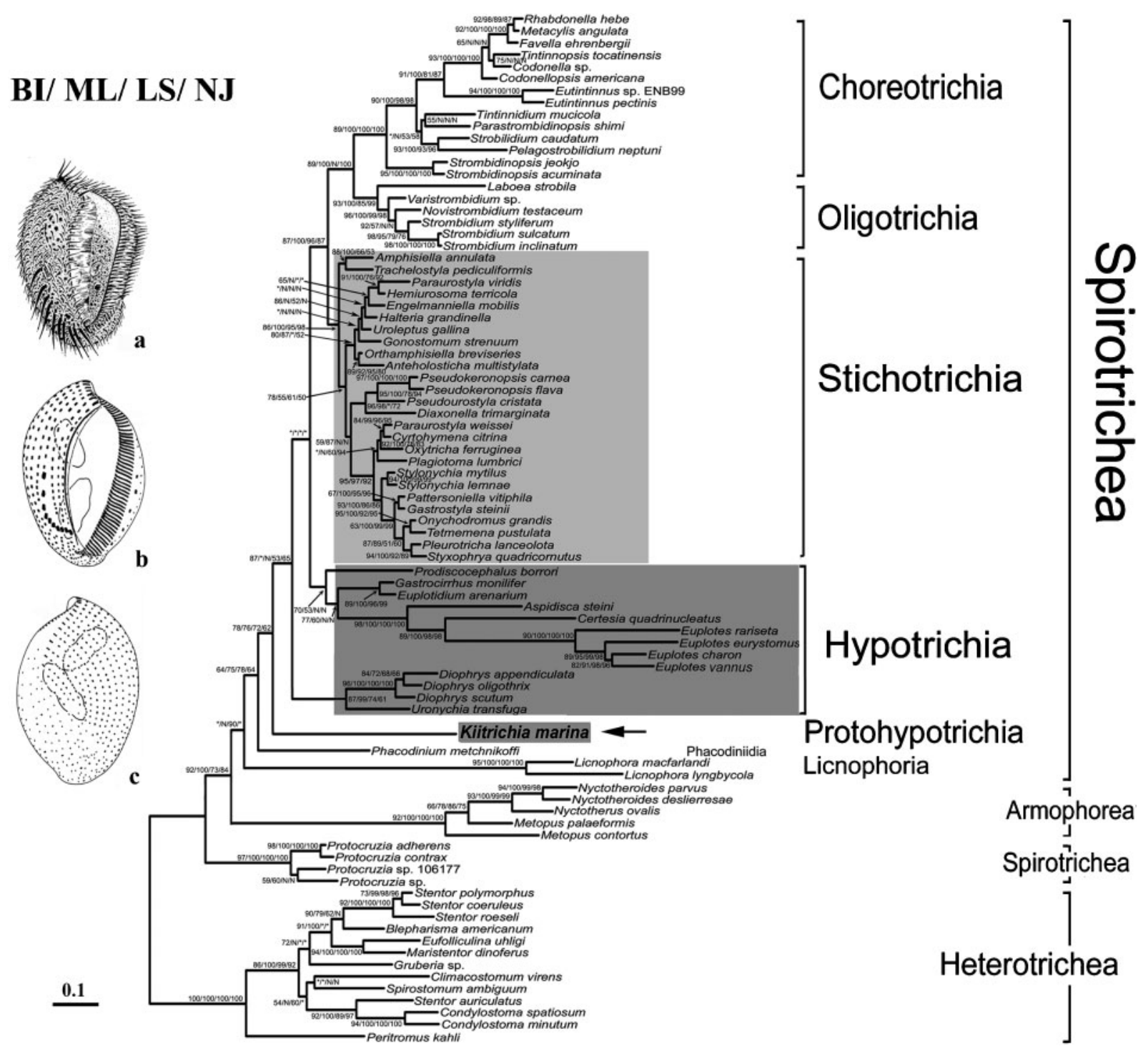

Fig. 2. Bayesian tree inferred from nucleotide sequences of the SSU rRNA gene of armophorean, spirotrich and heterotrich ciliates. Numbers at nodes represent support values in the following order: Bayesian credibility value using MrBayes and ML/ LS/NJ bootstrap percentages based on 1000 replicates. Asterisks indicate values less than $50 \%$; $\mathrm{N}$ indicates that the node was not recovered using this treeing method. Evolutionary distance is represented by the branch length. Bar, 10 substitutions per 100 nucleotide positions. The new sequence for K. marina is highlighted in bold. Insets: (a) ventral view of a typical individual of K. marina in vivo; (b, c) ventral and dorsal views of the same specimen impregnated by the protargol method. 
and 30 cycles of denaturation at $94{ }^{\circ} \mathrm{C}$ for $1 \mathrm{~min}$, annealing at $60{ }^{\circ} \mathrm{C}$ for $2 \mathrm{~min}$ and extension at $72{ }^{\circ} \mathrm{C}$ for $2 \mathrm{~min}$, followed by an additional extension at $72{ }^{\circ} \mathrm{C}$ for $10 \mathrm{~min}$. PCR products of the expected size were inserted into the pUCm-T vector (Sangon). A plasmid miniprep spin column kit (Sangon) was used to harvest and purify plasmid DNA. DNA sequencing was accomplished using an ABI Prism 3730 Automated DNA Sequencer (Applied Biosystems) with three forward and four reverse internal primers (Greenwood et al., 1991). All sequences were confirmed from both strands. Sequence fragments were assembled into continuous sequences and edited with the Sequencher 4.0 software package (GeneCodes Corp.).

Phylogenetic analyses and tree construction. Nucleotide sequences of the SSU rRNA gene were aligned using CLUSTAL W, version 1.80 (Thompson et al., 1994), and then the alignment was refined by removing ambiguous gaps at both termini of the alignment and considering the conserved secondary structures.

A $50 \%$ majority-rule Bayesian inference (BI) tree was constructed with MrBayes version 3.1.2 (Ronquist \& Huelsenbeck, 2003) using the Markov chain Monte Carlo (MCMC) algorithm under the GTR $+\mathrm{G}+\mathrm{I}$ evolutionary model indicated by MRMODELTEST version 2 (Nylander, 2004). The chain length was 1000000 generations, with trees sampled every 100 generations. The first 250000 generations were discarded as burn-in.

A maximum-likelihood (ML) tree was constructed with PAUP (version 4.0b10) (Swofford, 2002) using the $\operatorname{TrN}+\mathrm{I}+\mathrm{G}$ evolutionary model selected by MODELTEST (Posada \& Crandall, 1998) and an input file created by performing an accelerated likelihood surface exploration (Nixon, 1999; Vos, 2003) with the program PAUPRat (Sikes \& Lewis, 2001). A $50 \%$ majority-rule consensus ML tree was derived from the output of 200 trees generated by PAUP operating on the input file from PAUPRat.

PHYLIP version 3.57c (Felsenstein, 1995) was used to calculate sequence similarities and evolutionary distances between pairs of nucleotide sequences using Kimura's two-parameter model (Kimura, 1980). Distance-matrix trees were constructed using the least-squares (LS) method (Fitch \& Margoliash, 1967) and the neighbour-joining (NJ) method (Saitou \& Nei, 1987). Distance trees were bootstrapped 1000 times.

The topologies of the four trees were almost identical; therefore, the Bayesian tree was chosen as a representative for purposes of illustration. This tree was formatted with MEGA (Kumar et al., 2004) and exported from it as a graphics file for construction of the finished figure. For ease of viewing, it was rooted on 13 species of heterotrichs; this did not affect the topology of the spirotrichous portion of the tree.

Amino acid sequences deduced from alpha-tubulin gene sequences were aligned using CLUSTAL w version 1.80 (Thompson et al., 1994) and trimmed to the same length. MrBayes version 3.1.2 (Ronquist \& Huelsenbeck, 2003) was used to construct a Bayesian tree using the MCMC algorithm under the JTT evolutionary model (Jones et al., 1992) and considering a gamma-shaped distribution of rates of substitution among sites. The chain length for our analysis was 1000000 generations with trees sampled every 50 generations. The first 250000 generations were discarded as burn-in.

\section{RESULTS}

\section{SSU rRNA and alpha-tubulin gene sequences of K. marina}

The SSU rRNA gene sequence of $K$. marina is 1754 nucleotides in length, with a G $+\mathrm{C}$ content of $43.9 \mathrm{~mol} \%$.
K. marina exhibits the highest sequence similarity to the stichotrichs $(84.31-86.09 \%)$. The similarities to other groups are $84.47 \%$ to Phacodinium, $82.29-84.4 \%$ to oligotrichs, $81.94-84.68 \%$ to choreotrichs, $82.6-83.55 \%$ to Protocruzia, $79.92-81.73 \%$ to Licnophora, $78.59-85.6 \%$ to hypotrichs and $78.44-80.65 \%$ to heterotrichs.

The partial alpha-tubulin gene sequence obtained for $K$. marina is 1071 nucleotides in length, encoding 357 amino acids. The deduced alpha-tubulin amino acid sequence of K. marina shows $79.35-81.76 \%$ similarity to choreotrichs, $68.72-70.83 \%$ to hypotrichs, $67.74-76.25 \%$ to stichotrichs, $63.47-80.56 \%$ to oligotrichs and $60.01 \%$ to Phacodinium.

\section{Morphogenetic features during binary fission (Fig. 1)}

Fig. 1 documents the main stages of general cortical development during binary division of $K$. marina, which is characterized by numerous unique features (details will be published separately) that are not observed in any other known spirotrich: (i) no new undulating membranes (UM)-anlage in the opisthe is formed, hence the UM in the opisthe are derived from the division of the dedifferentiated parental ones; (ii) no marginal cirral rows are formed; (iii) no typical DK are generated (i.e. several rows of pre-DK consisting of dikinetids with both basal bodies ciliated appear to mix with either isolated small cirri or cirral fragments); (iv) all cirral anlagen are formed interkinetally from the de-differentiated old cirral rows; and, (v) unlike all other known hypotrichs (s. l.), the differentiation of ciliature from the primordia occurs mostly after cell division. In addition, the general cirral structures on the ventral side are in a post-anlage pattern: except for the transverse cirri, all other cirri exhibit a primary arrangement (i.e. they are evenly distributed as if they had just been segregated from the anlagen).

\section{Phylogenetic analyses using SSU rRNA gene sequences (Fig. 2)}

Phylogenetic trees indicated that Kiitricha branches basally from the spirotrichous clade at a very deep level (Fig. 2). In our analyses, the spirotrichs are not a monophyletic taxon: armophorean genera separate Protocruzia species from the other spirotrichs. Licnophora is a basal lineage within the class Spirotrichea (Lynn \& Strüder-Kypke, 2002). Associated with Phacodinium, Kiitricha branches at the base of the hypotrichs (s. l.) and represents a distinct clade from all other spirotrich taxa, with moderate bootstrap support (BI $78 \%$, ML $76 \%$, LS $72 \%$, NJ $62 \%$ ).

\section{Bayesian analyses using alpha-tubulin gene sequences (Fig. 3)}

The Bayesian tree for alpha-tubulin gene sequences supports the monophyly of the five classes sensu Lynn 


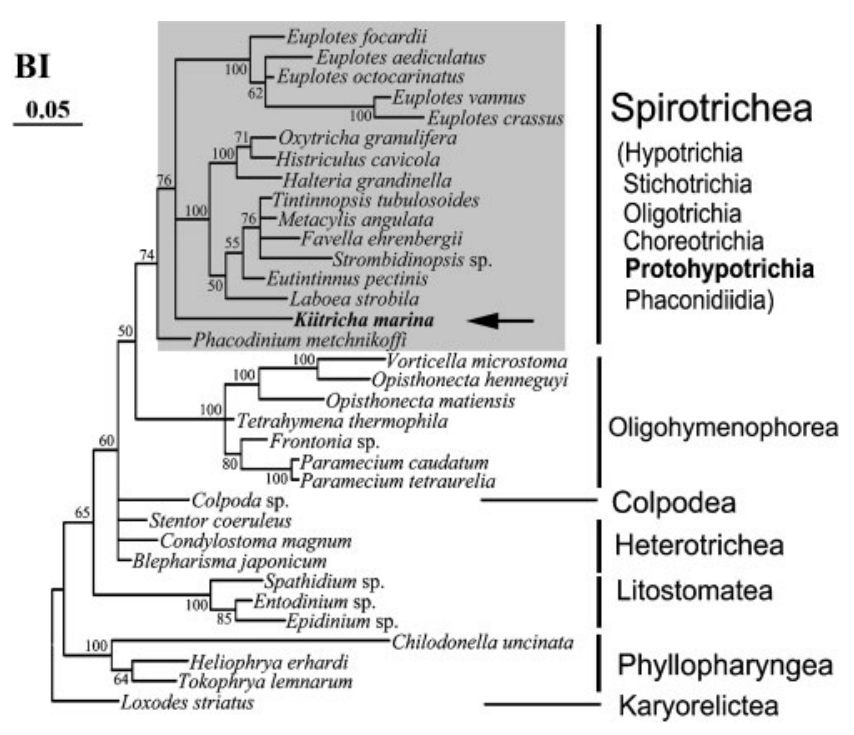

Fig. 3. Bayesian tree inferred from alpha-tubulin amino acid sequences. The new sequence for $K$. marina is highlighted in bold. Evolutionary distance is represented by branch lengths. Bar, 5 substitutions per 100 amino acid positions.

(2003) from which more than one species representative is available in the alpha-tubulin dataset: Spirotrichea, Oligohymenophorea, Phyllopharyngea, Litostomatea and Heterotrichea. However, there is poor resolution of the three species within the class Heterotrichea. Kiitricha diverges after Phacodinium within an unresolved trichotomy of spirotrichs.

\section{Cladistic analyses based on morphological and morphogenetic characters (Fig. 4)}

A hypothesis on the potential position of Kitricha was predicted based on autapomorphic characters listed in Table 1. As a result of the pattern of stomatogenesis and cirral differentiation, Phacodiniida and Licnophorida appear closer to heterotrichs rather than the euplotidstichotrich clade. Kiitricha represents a distinct branch at the base of the euplotid-stichotrich clade, with apokinetal stomatogenesis and differentiated cirri but lacking UManlage and differentiated marginal cirral rows (Fig. 4). Different from the arrangement suggested by Lynn \& Small (2002), discocephalids group with sporadotrichids (i.e. Stylonychia, Oxytricha etc.) and diverge from the euplotid clade (i.e. Aspidisca, Uronychia, Diophrys and Euplotes).

\section{DISCUSSION}

The genus Kiitricha demonstrates a number of unique features that significantly separate it from other spirotrichs and may represent the type of a higher taxon; Shi et al. (1999) suggested the 'suborder' Protohypotrichina.

Alignment of sequences clearly showed similarities in primary structure and $\mathrm{G}+\mathrm{C}$ content of the SSU rRNA gene of Kiitricha to those of other ciliates. The $\mathrm{G}+\mathrm{C}$ content (43.9 mol\%) of the SSU rRNA gene of $K$. marina is in the same range as those of other ciliates (Elwood et al., 1985; Sogin \& Elwood, 1986; Schlegel et al., 1991; Chen \& Song, 2002; Li \& Song, 2006). Thus, this aspect of the gene should not bias our phylogenetic analyses. In all our analyses of the SSU rRNA gene, Kiitricha grouped with other spirotrichs, switching positions with another unusual spirotrich genus, Phacodinium. Thus, there is no doubt that Kiitricha is a spirotrich.

Based on ultrastructural features and analyses of some gene sequences, particularly the SSU rRNA and large-subunit rRNA genes, Lynn \& Small (1997) presented a revised classification of the phylum Ciliophora, which included 10 classes, 17 subclasses and 57 orders. The class Spirotrichea Bütschli, 1889 contained five subclasses (Protocruziidia, Hypotrichia, Choreotrichia, Oligotrichia and Stichotrichia) and four sedis mutabilis orders (Armophorida, Clevelandellida, Phaconidiidia and Odontostomatida). Shin et al. (2000) placed Phacodinium into the spirotrich clade based on its SSU rRNA gene sequence, justifying the establishment of the subclass Phacodiniidia. Lynn \& Strüder-Kypke (2002) added a seventh monotypic subclass to the spirotrichs when they recognized Licnophora as the type for the subclass Licnophoria using SSU rRNA gene

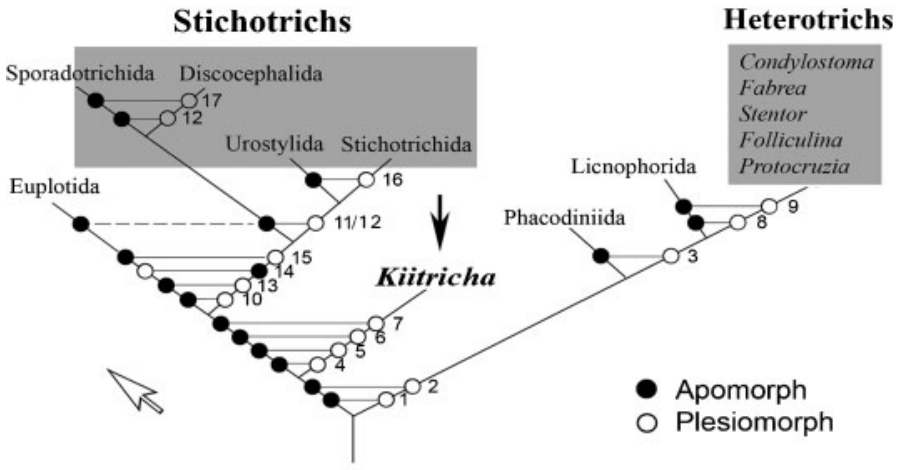

Lower ciliates
Fig. 4. Phylogenetic position of Kiitricha based on morphogenetic and morphological characters (see Table 1). Arrow indicates the evolutionary direction. Apomorphic characters are indicated by filled circles, whereas plesiomorphic characters are indicated by open circles. 
Table 1. Autapomorphies considered in assessment of the phylogenetic position of Kiitricha

Data were taken from Berger (1999, 2006), Diener et al. (1983), Eigner \& Foissner (1994), Foissner (1996), Grolière et al. (1980), Roque (1970), Shao et al. (2006), Song \& Wilbert (1997), Song et al. (2004), Villeneuve-Brachon (1940) and Wicklow (1982).

\begin{tabular}{|c|c|}
\hline Apomorph & Plesiomorph \\
\hline 1. Stomatogenesis in apokinetal mode & Parakinetal mode \\
\hline 2. Cirri present and clearly differentiated & $\begin{array}{l}\text { No cirri formed; somatic ciliature uniform and consisting of } \\
\text { longitudinal rows of dikinetids }\end{array}$ \\
\hline 3. Semi-cirri^ present in somatic ciliature & Uniform kineties consisting of dikinetids \\
\hline $\begin{array}{l}\text { 4. } \mathrm{UM} \text { in the opisthe formed de novo and together with the oral } \\
\text { primordium }\end{array}$ & $\begin{array}{l}\text { No new anlage for UM is formed; it generates from division of the } \\
\text { UM-anlage of the proter }\end{array}$ \\
\hline 5. Marginal rows clearly differentiated & Marginal rows not differentiated \\
\hline 6. First frontal cirrus formed from UM-anlage & No frontal cirrus formed from the UM-anlage \\
\hline 7. Basal bodies in DK in typical hypotrichous pattern & In heterotrichous pattern \\
\hline 8. Somatic ciliature highly reduced or degenerative & Developed or specialized, not degenerative \\
\hline $\begin{array}{l}\text { 9. Both ciliature and body shape highly specialized, ectocommensal } \\
\text { with adhesive disc }\end{array}$ & Generally non-specialized, non-commensal \\
\hline 10. Stomatogenesis in subapokinetal mode & In epi-apokinetal mode \\
\hline 11. Number of cirral streaks stable & Variable \\
\hline 12. Five-FVT-cirrus-anlagen mode & Non-five-cirrus-anlagen mode \\
\hline 13. Right marginal row absent & Present \\
\hline 14. DK formed in secondary pattern & In primary pattern \\
\hline 15. Silverline system often highly group-dependent & Non-specialized, non-group-dependent \\
\hline 16. Cirri in mid-ventral rows in zigzag pattern & Not in pattern, low level of organization \\
\hline 17. Cirri in most area stable in number & Mostly variable in number \\
\hline
\end{tabular}

${ }^{\star}$ Concerns the somatic ciliature of longitudinal rows, in which monokinetids are formed in single-rowed fragments.

sequence analyses, and by confirming that its replication bands clearly demonstrated its affinities with the spirotrichs, but not heterotrichs.

The class Armophorea was suggested by Lynn (2003) as the first 'ribo-class' inferred from SSU rRNA gene sequence analyses and including the orders Armophorida and Clevelandellida. Recently, Stoeck et al. (2007) have preliminary evidence that some odontostomatids may be related to the class Plagiopylea.

Lynn \& Small $(1997,2002)$ placed Kiitricha in the subclass Hypotrichia Stein, 1859 and its family was the type for the hypotrich order Kiitrichida.

The genus Kiitricha, which is clustered basally within the spirotrich clade in all our analyses based on the SSU rRNA and alpha-tubulin gene sequences, represents a distinct clade, remotely related to all other spirotrich taxa. Thus, its position as a type for a larger taxon appears to be justified. Since Phacodinium and Licnophora both represent types for monotypic subclasses of spirotrichs and Kiitricha is similarly isolated, we support Shi et al. (1999) and suggest the recognition of a new subclass of spirotrichs, the subclass Protohypotrichia, based on the suborder Protohypotrichina Shi, Song \& Shi, 1999. The new taxon contains a single order, Kiitrichida Nozawa, 1941, and could be diagnosed as follows: Spirotrichea with weakly differentiated and non-grouped somatic ciliature (i.e. cirri on ventral side generally uniform, no clearly defined marginal cirral rows, ciliature on dorsal side mixed with cirri and dikinetids, no clearly differentiated dorsal kineties) and a unique morphogenetic pattern of cortical structures, intermediate between Hypotrichia and Stichotrichia. In contrast to Shi et al. (1999), who included two families (i.e. Phacodiniidae and Kiitrichidae) in the suborder Protohypotrichina, we transfer the following taxa to the new subclass as they were assigned to the order Kiitrichida sensu Lynn \& Small, 2002: Kiitrichidae Nozawa, 1941 and Reichenowellidae Kahl, 1932.

In support of the removal of the kiitrichids from the subclass Hypotrichia, it is useful to review the morphogenetic features of typical euplotids. Euplotids are a monophyletic assemblage united by the following pattern of development of the infraciliature: (i) the FVT-cirri are formed apokinetally in a five-anlagen mode; (ii) marginal rows are present or reduced; (iii) both ventral and dorsal ciliatures have a very stable pattern; (iv) DK are clearly differentiated with typical dikinetids as seen in all other typical spirotrichs (probably except Licnophora) and (v) the UM-anlage in the opisthe is formed independently within a subcortical pouch together with the oral primordium (Song \& Packroff, 1993; Song et al., 2004). Compared with these euplotid features, all characters revealed during morphogenesis in K. marina indicate that this organism should be a primitive form and totally isolated from euplotids and other known hypotrichs (s. l.). 
Hence, we conclude from both the molecular and morphological/morphogenetic data that the order Kiitrichida represents a distinct taxon within the class Spirotrichea and should be placed in the subclass Protohypotrichia. Indeed, an expanded investigation of the order Kiitrichida is now needed to determine whether the other families and genera assigned to this taxon are properly placed.

\section{ACKNOWLEDGEMENTS}

This work was supported by the Nature Science Foundation of China (project numbers 40676076 and 30670280; awarded to W.S. and Z.C.) and the Natural Sciences and Engineering Research Council of Canada (awarded to D. H. L.).

\section{REFERENCES}

Berger, H. (1999). Monograph of the Oxytrichidae (Ciliophora, Hypotrichia) (Monographiae Biologicae vol. 78). Dordrecht: Springer.

Berger, H. (2006). Monograph of the Urostyloidea (Ciliophora, Hypotricha) (Monographiae Biologicae vol. 85). Heidelberg: Springer.

Chen, Z. \& Song, W. (2002). Phylogenetic positions of Aspidisca steini and Euplotes vannus within the order Euplotida (Hypotrichia: Ciliophora) inferred from complete small subunit ribosomal RNA gene sequences. Acta Protozool 41, 1-9.

Corliss, J. O. (1979). The Ciliated Protozoa: Characterization, Classification and Guide to the Literature, 2nd edn. Oxford: Pergamon.

De Puytorac, P. (1994). Phylum Ciliophora Doflein, 1901. In Traité de Zoologie, Tome II, Infusoires Ciliés, Fasc. 2, Systématoque, pp. 1-15. Edited by P. de Puytorac. Masson: Paris (in French).

Diener, D. R., Burchill, B. R. \& Burton, P. R. (1983). Microtubules and filaments beneath the fission furrow of Stentor coeruleus. J Eukaryot Microbiol 30, 83-90.

Eigner, P. \& Foissner, W. (1994). Divisional morphogenesis in Amphisiellides illuvialis n. sp., Paramphisiella caudata (Hemberger) and Hemiamphisiella terricola Foissner and redefinition of the Amphisiellidae (Ciliophora, Hypotrichida). J Eukaryot Microbiol 41, 243-261.

Elwood, H. J., Olsen, G. J. \& Sogin, M. L. (1985). The small-subunit ribosomal RNA gene sequences from the hypotrichous ciliates Oxytricha nova and Stylonychia pustulata. Mol Biol Evol 2, 399-410.

Felsenstein, J. (1995). PHYLIP: phylogeny inference package, version 3.57c. Department of Genome Sciences, University of Washington, Seattle, USA.

Fitch, W. M. \& Margoliash, E. (1967). Construction of phylogenetic trees. Science 155, 279-284.

Foissner, W. (1996). Ontogenesis in ciliated protozoa, with emphasis on stomatogenesis. In Ciliates: Cells as Organisms, pp. 95-177. Edited by K. Hausmann \& P. C. Bradbury. Stuttgart: Gustav Fischer.

Greenwood, S. J., Sogin, M. L. \& Lynn, D. H. (1991). Phylogenetic relationships within the class Oligohymenophorea, phylum Ciliophora, inferred from the complete small subunit rRNA gene sequences of Colpidium campylum, Glaucoma chattoni, and Opisthonecta henneguyi. J Mol Evol 33, 163-174.

Grolière, C. A., Puytorac, P. \& Detcheva, R. (1980). A propos d'observations sur la stomatogenése et l'ultrastructure du cilié Protocruzia tuzeti Villeneuve-Brachon, 1940. Protistologica 16, 453 466 (in French).
Hammerschmidt, B., Schlegel, M., Lynn, D. H., Leipe, D. D., Sogin, M. L. \& Raikov, I. B. (1996). Insights into the evolution of nuclear dualism in the ciliates revealed by phylogenetic analysis of rRNA sequences. J Eukaryot Microbiol 43, 225-230.

Jones, D. T., Taylor, W. R. \& Thornton, J. M. (1992). The rapid generation of mutation data matrices from protein sequences. Comput Appl Biosci 8, 275-282.

Kimura, M. (1980). A simple method of estimating evolutionary rates of base substitutions through comparative studies of nucleotide sequences. J Mol Evol 16, 111-120.

Kumar, S., Tamura, K. \& Nei, M. (2004). MEGA3: integrated software for molecular evolutionary genetics analysis and sequence alignment. Brief Bioinform 5, 150-163.

Li, L. \& Song, W. (2006). Phylogenetic position of the marine ciliate, Certesia quadrinucleata (Ciliophora; Hypotrichia; Hypotrichida) inferred from the complete small subunit ribosomal RNA gene sequence. Eur J Protistol 42, 55-61.

Lynn, D. H. (2003). Morphology or molecules: how do we identify the major lineages of ciliates (phylum Ciliophora)? Eur J Protistol 39, 356-364.

Lynn, D. H. (2008). The Ciliated Protozoa: Characterization, Classification, and Guide to the Literature, 3rd edn. Dordrecht: Springer.

Lynn, D. H. \& Small, E. B. (1997). A revised classification of the phylum Ciliophora Doflein, 1901. Rev Soc Mex Hist Nat 47, 65-78.

Lynn, D. H. \& Small, E. B. (2002). Phylum Ciliophora Doflein, 1901. In An Illustrated Guide to the Protozoa, 2nd edn, pp. 371-656. Edited by J. J. Lee, G. F. Leedale \& P. C. Bradbury. Lawrence, KS: Society of Protozoologists.

Lynn, D. H. \& Strüder-Kypke, M. C. (2002). Phylogenetic position of Licnophora, Lechriopyla, and Schizocaryum, three unusual ciliates (phylum Ciliophora) endosymbiotic in echinoderms (phylum Echinodermata). J Eukaryot Microbiol 49, 460-468.

Nixon, K. C. (1999). The parsimony ratchet, a new method for rapid parsimony analysis. Cladistics 15, 407-414.

Nylander, J. A. A. (2004). MrModeltest version 2. Distributed by the author. Department of Systematic Zoology, Evolutionary Biology Centre, Uppsala University, Sweden.

Posada, D. \& Crandall, K. A. (1998). MODELTEST: testing the model of DNA substitution. Bioinformatics 14, 817-818.

Ronquist, F. \& Huelsenbeck, J. P. (2003). MrBayes 3: Bayesian phylogenetic inference under mixed models. Bioinformatics 19, 15721574.

Roque, M. (1970). Observation sur Phacodinium metchnicoffi Certes, 1891. Ann Stat Biol 5, 297-302 (in French).

Saitou, N. \& Nei, M. (1987). The neighbor-joining method: a new method for reconstructing phylogenetic trees. Mol Biol Evol 4, 406-425.

Schlegel, M., Elwood, H. J. \& Sogin, M. L. (1991). Molecular evolution in hypotrichous ciliates: sequence of the small subunit RNA genes from Onychodromus quadricornutus and Oxytricha granulifera (Oxytrichidae, Hypotrichida, Ciliophora). J Mol Evol 32, 64-69.

Shao, C., Song, W., Hu, X., Ma, H., Zhu, M. \& Wang, M. (2006). Cell division and morphology of the marine ciliate, Condylostoma spatiosum Ozaki and Yagiu (Ciliophora, Heterotrichida) based on a Chinese population. Eur J Protistol 42, 9-19.

Shi, X. L., Song, W. \& Shi, X. B. (1999). Systematic revision of the hypotrichous ciliates. In Progress in Protozoology, pp. 77-154. Edited by W. Song, X. L. Shi, X. Hu, Y. Lei, J. Wei, Z. Chen, X. B. Shi \& M. Wang. Qingdao: Qingdao Ocean University Press (in Chinese).

Shin, M. K., Hwang, U. W., Kim, W., Wright, A.-D. G., Krawczyk, C. \& Lynn, D. H. (2000). Phylogenetic position of the ciliates Phacodinium (order Phacodiniida) and Protocruzia (subclass Protocruziidia) and 
systematics of the spirotrich ciliates examined by small subunit ribosomal RNA gene sequences. Eur J Protistol 36, 293-302.

Sikes, D. S. \& Lewis, P. O. (2001). PAUPrat. A tool to implement parsimony and likelihood ratchet searches using PAUP*. Distributed by the authors. Department of Ecology and Evolutionary Biology, University of Connecticut, Storrs, CT, USA.

Small, E. B. \& Lynn, D. H. (1985). Phylum Ciliophora. In $A n$ Illustrated Guide to the Protozoa, pp. 393-575. Edited by J. J. Lee, S. H. Hutner \& E. C. Bovee. Lawrence, KS: Society of Protozoologists.

Sogin, M. L. \& Elwood, H. J. (1986). Primary structure of the Paramecium tetraurelia small-subunit rRNA coding region: phylogenetic relationships within the Ciliophora. J Mol Evol 23, 53-60.

Song, W. \& Packroff, G. (1993). Beitrag zur Morphogenese des marinen Ciliaten Diophrys scutum (Dujardin, 1841). Zool Jahrb Abt Anat Ontogenie Tiere 123, 85-95 (in German).

Song, W. \& Wilbert, N. (1997). Morphological studies on some free living ciliates (Ciliophora: Heterotrichida, Hypotrichida) from marine biotopes in Qingdao, China, with descriptions of three new species: Holosticha warreni nov. spec., Tachysoma ovata nov. spec. and T. dragescoi nov. spec. Eur J Protistol 33, 48-62.

Song, W., Wilbert, N., Chen, Z. \& Shi, X. (2004). Considerations on the systematic position of Uronychia and related euplotids based on the data of ontogeny and 18S rRNA gene sequence analyses, with morphogenetic redescription of Uronychia setigera Calkins, 1902 (Ciliophora, Euplotida). Acta Protozool 43, 313-328.

Stoeck, T., Foissner, W. \& Lynn, D. H. (2007). Small subunit rRNA phylogenies suggest that Epalxella antiquorum (Penard, 1922) Corliss, 1960 (Ciliophora, Odontostomatida) is a member of the Plagiopylea. J Eukaryot Microbiol 54, 436-442.

Swofford, D. L. (2002). PAUP*. Phylogenetic Analysis using Parsimony (* and other methods). Sunderland, MA: Sinauer.

Thompson, J. D., Higgins, D. G. \& Gibson, T. J. (1994). CLUSTAL W: improving the sensitivity of progressive multiple sequence alignment through sequence weighting, position-specific gap penalties and weight matrix choice. Nucleic Acids Res 22, 4673-4680.

Villeneuve-Brachon, S. (1940). Recherches sur les ciliés hétérotriches, cinétome, argyrome, myonèmes formes nouvelles ou peu connues. Arch Zool Exp Gen 82, 1-180 (in French).

Vos, R. A. (2003). Accelerated likelihood surface exploration: the likelihood ratchet. Syst Biol 52, 368-373.

Wicklow, B. J. (1982). The Discocephalina (n. subord.): ultrastructure, morphogenesis and evolutionary implications of a group of endemic interstitial hypotrichs (Ciliophora, Protozoa). Protistologica 18, 299330. 